\title{
EUs oversøiske lande og territorier: postkoloniale suverænitetsspil og Grøn- lands arktiske muligheder
}

Ulrik Pram Gad phd, post.doc., Center for Advanced Security Theory, Københavns Universitet, email: upg@ifs.ku.dk

Ida Hannibal cand.scient.pol., fuldmægtig, Finansministeriet, email: ida_hannibal@hotmail.com. Kristine Holst cand.scient.pol., videnskabelig ass., Institut for Statskundskab, Københavns Universitet, email: holst.kristine@gmail.com

Rebecca Adler-Nissen phd, adjunkt, email: ran@ifs.ku.dk, Institut for Statskundskab, Københavns Universitet

EU forbereder i øjeblikket en reform af forholdet til medlemslandenes 21 oversøiske lande og territorier. Grønlands ønsker til reformen skiller sig markant ud ved delvist at italesætte en fremtidig relation til EU som et ligeværdigt forhold. I modsætning hertil forbliver de øvrige oversøiske lande og territorier inden for en postkolonial diskurs om ensidig bistand. En væsentlig ressource i konstruktionen af de „westfalske“ elementer i det grønlandske svar er en forestilling om uudnyttede ressourcer og muligheder i det arktiske.

\section{Indledning: mellem koloni og suveræn stat}

Hvordan bliver tidligere kolonier og sårbare ø-samfund som Grønland hørt på den internationale scene? Hvilke argumenter anvender de over for internationale organisationer som EU, der tilbyder nye former for bistand og samarbejde men også stiller store krav? Med et særligt fokus på Grønland undersøger denne artikel, hvordan tidligere kolonier opnår en særlig form for subjektivitet gennem deres tilknytning til det supranationale EU. Dette spørgsmål er relevant for vores viden om Grønlands og andre sårbare og angiveligt svage aktørers internationale handlemuligheder. Men spørgsmålet er også væsentligt i en bredere kontekst, nemlig for vores forståelse af forholdet mellem postkolonialisme og europæisk integration. Konkret videreudvikler denne artikel Georg Sørensens begreb om suverænitetsspil ved at tilsætte en retorisk dimension. Nærmere bestemt tilfører vi et Toulminsk argumentationsteoretisk element. Dermed bliver suverænitetsspil udtryk for mere end blot en særlig materiel og institutionel ressourcefordeling. Suverænitetsspil kan ses som særlige argumentatoriske strategier, der trækker på suverænitetsbegrebet. Resultatet bliver et mere dynamisk og nuanceret billede af international politik og særligt forholdet mellem tidligere kolonier, tidligere kolonisatorer og internationale organisationer. Før vi kaster os over teorien, er det imidlertid nødvendigt at opridse den historiske baggrund.

Opløsningen af de europæiske imperier efter anden verdenskrig betød, at det spæde europæiske samarbejde, der senere blev til EU, måtte forholde sig aktivt til afkolonialiseringen. De tidligere kolonier er i dag opdelt i tre forskellige grupper med hver deres politiske og økonomiske relation til EU. Den største gruppe er AVS-landene i Afrika (syd for Sahara), Vestindien og Stillehavsområdet, der alle er blevet selvstændige stater, og som EU har indgået et særligt udviklingspolitisk samarbejde med. Dernæst er der de fjerntliggende regioner, som nu er integrerede dele af det land, de har været koloniseret af. I denne gruppe finder vi eksempelvis Fransk Guyana og Martinique. De fjerntliggende regioner er en del af EU på lige fod med områder, der geografisk er placeret på det europæiske kontinent.

Endelig er der en gruppe af Oversøiske Lande og Territorier (OLTerne), der falder imellem de to førnæunte kategorier: De er hverken selvstændige eller fuldbyrdige dele af en selvstændig stat. Men de er heller ikke 'blot' kolonier som i gamle dage - for de har hver deres mere el- 
ler mindre udbyggede selvstyreordning. OLT-kategorien blev indskrevet i den oprindelige Rom-traktat i 1957 for at give plads til især de franske kolonier i Afrika. Relationen mellem EU og OLTerne er traktatfæstet i fjerde del af traktaten (artikel 198-204 og 355(2) TEUF') og reguleres af såkaldte associeringsafgørelser („OLT-ordningen“) der genforhandles hvert tiende år. I dag omfatter kategorien 21 større eller mindre øer eller øgrupper som Grønland, Fransk Polynesien, de Nederlandske Antiller og de Britiske Jomfruøer tilknyttet fire medlemsstater (Danmark, Frankrig, Holland og Storbritannien) - de såkaldte „moderlande“. Øerne, der tilsammen mønstrer en befolkning på knap 1,25 mio. indbyggere, er sårbare og yderst afhængige af omverdenen pga. deres lille befolkning, deres udsathed over for klimaforandringer og deres (ofte) geografiske isolation (Kommissionen 2008, 3).

I sammenligning med AVS-landenes og de fjerntliggende regioners relation til EU forekommer OLTernes position imidlertid bemærkelsesværdig favorabel. OLTerne har således fået en af de mest gunstige handels- og toldordninger, EU nogensinde har bevilliget, og får desuden en udviklingsbistand, der er godt seks gange højere pr. indbygger end gennemsnittet for AVS-landene (Kommissionen 2008, 5). Samtidig er de pligter, der konkret påhviler OLTerne i kraft af det nuværende partnerskab med EU, fortsat stærkt begrænsede (Kommissionen 2008, 9-10). OLTerne skal eksempelvis ikke implementere al EU-lovgivning i modsætning til de fjerntliggende regioner. Denne historisk betingede position er nu sat til diskussion. Revisionen af OLT-ordningen kan vise sig at blive en skillevej, der vil forandre OLTernes vilkår fremover.

Hvad OLTerne i praksis kan og gør i EU-regi er fuldstændig uafdækket i et politologisk perspektiv. ${ }^{2}$ Der er imidlertid forskellige teoretiske bud på, hvad vi kan forvente af OLTernes internationale deltagelses- og indflydelsesmuligheder. Traditionelle statscentriske forståelser af international politik har svært ved at håndtere størrelser, der ikke er selvstændige stater. I den dominerende tænkning i international politik forstås perifere områder som OLTerne alene som objekter for dominerende spilleres handlinger (f.eks. hovedstaden eller store stater). De ses derfor som uden „subjektivitet" og er uinteressante i studiet af international politik (Browning \& Joenniemi 2004, 700). Subjektivitet skal her forstås som kombinationen af identitet (en selvopfattelse som handlende subjekt) og agens eller handlingsformån (et handlerum for at kunne agere som et subjekt) (Browning \& Joenniemi 2004, 721; 701). Muligheden for at opnå subjektivitet går inden for den dominerende tænkning alene gennem suverænitet (Browning \& Joenniemi 2008, 144). For at nuancere dette traditionelle blik for hvilke typer af sub- jektivitet, der er mulige i international politik, indfører vi begrebet suverænitetsspil (Sørensen 1999). Det gør os i stand til at analysere de forhandlinger om goder/pligter og rettigheder/ansvar, som udspiller sig med udgangspunkt i suverænitetsbegrebet. Det betyder også, at suverænitet ikke reduceres til et enten-eller-spørgsmål.

Denne artikel undersøger, hvordan OLTerne udviser subjektivitet. Spørgsmålet om, i hvilken grad OLTerne kan opnå selvstændig indflydelse og handlerum, er vigtig netop nu, hvor man står midt $\mathrm{i}$ den revision af OLT-ordningen, som gennemføres cirka hvert 10. år, Aktuelt forhandles altså om OLTernes fremtidige tilhørsforhold til EU, og hvilke goder og pligter, de skal have i EU-regi. Kommissionen fremlagde i 2008 som oplæg til forhandlingerne en grønbog, ${ }^{3}$ der lægger op til en større nytænkning og modernisering af relationen. Dette bl.a. med henblik på at bevæge sig væk fra princippet om fattigdomsbekæmpelse, der indtil nu har været omdrejningspunktet for ordningen, men som ikke længere er tidssvarende i forhold til alle OLTernes højere udviklingsniveau (Udenrigsministeriet 2009, 29). Når revisionen af OLT-ordningen i sidste ende fastlægges i Rådet, sidder OLTerne selvsagt ikke med ved bordet. Sammen med påvirkningen af „moderlandet“ er svar til Kommissionens grønbog derfor de helt centrale indflydelsesveje for OLTerne. Konkret undersøger artiklen, hvilke argumentatoriske strategier, OLTerne anvender i deres svar på Kommissionens reformudspil - og hvordan disse strategier placerer OLTerne inden for forskellige typer af suverænitetsspil.

Artiklen falder i fire dele: Først introduceres Georg Sørensens typologi over forskellige suverænitetsspil og vores retoriske videreudvikling. Derpå redegøres for valget af analytisk materiale og den anvendte tekstlæsningsstrategi. Tredje del identificerer de grundlæggende argumentatoriske strategier, OLTerne anvender i forhold til Kommissionen: OLTerne italesætter sig primært som placeret $\mathrm{i}$ et postkolonialt asymmetrisk suverænitetsspil, hvor de har ret til støtte fra EU uden at skulle bidrage med noget den anden vej. I denne forbindelse optræder bl.a. klimaforandringerne som argument for OLTernes sårbarhed og afhængighed. I visse tilfælde iklædes det postkoloniale subjekt postmoderne klæder, når såvel EU som OLTerne italesættes som spillere, der ikke lægger så meget vægt på traditionel suverænitet, men gerne slår pjalterne sammen ud fra argumenter om fælles værdier og gensidige gevinster. Dette kræver dog i OLTernes argumentation støtte fra EU. Endelig identificeres i Grønlands svar enkelte eksempler på en positionering i et traditionelt, westfalsk landskab, hvor samarbejde består i konkrete byttehandler baseret på argumenter om noget-for-noget og nulsumsspil. Afslutningsvis konkluderer artiklen, at 
Grønland i konstruktionen af de „westfalske“ elementer i sit svar trækker på traditionelle geostrategiske forestillinger kombineret med ideer om uudnyttede ressourcer og muligheder gjort tilgængelige i det arktiske af klimaforandringerne. Disse forestillinger åbner muligheder for Grønland, som ikke er til rådighed for de øvrige OLTer.

\section{Teori: Suverænitetsspil og argumentatoriske stra- tegier}

Suverænitet defineres ofte som udtryk for eksklusiv autoritet over et territorium (Philpott 2001, 6). Med denne forståelse må man på den ene side konstatere, at der sker en række væsentlige ændringer af udøvelsen af suverænitet, særligt i EU (Walker 2003; 2008). På den anden side er det tydeligt, at suverænitetsinstitutionen som normativt udgangspunkt for den aktuelle indretning af international politik opretholder sin relevans. I den situation er det centralt at se nærmere på forskellige afvigelser fra traditionel suverænitet. Professor i international politik Georg Sørensen (1999) tager netop afsæt i afvigelserne fra konventionel suverænitetspraksis, idet han identificerer tre idealtypiske suverænitetsspil: Ud over det westfalske er der et postkolonialt og et postmoderne spil. De forskellige typer af suverænitetsspil indebærer, som vi vil vise, forskellige fordelinger af pligter, goder og ansvar. Dermed tilbyder Sørensen et frugtbart udgangspunkt for at forstå, hvordan aktører kan argumentere for forskellige typer af relationer, der skal gælde mellem OLTerne og EU.

Sørensen tager udgangspunkt i tre elementer af suverænitet, som er henholdsvis stabile og varierende. Den vedvarende komponent i suverænitetsbegrebet og -spillene er de konstitutive regler, der angiver, hvem der kan være stater i det internationale samfund samt det definitoriske indhold af suverænitet: Anerkendelse af staters konstitutionelle uafhængighed. Ændringer i suverænitetsspil sker gennem ændringer i de regulative regler og normer, hvor Sørensen fremhæver grundnormerne ikke-intervention og reciprocitet. Oftere sker forandring imidlertid gennem ændring i empirisk statslighed ${ }^{4}$, der omhandler strukturen og indholdet af stater/enheders økonomi og polity samt relationen mellem nation og stat (Sørensen 1999, 594598). Sørensens idealtyper indeholder både overvejelser omkring den idealtypiske stat inden for hver kategori og det idealtypiske spil.

I det westfalske spil er de idealtypiske stater moderne og udviklede med en selvbærende national økonomi (Sørensen 1999, 599). Politisk har de et effektivt institutionelt maskineri baseret på rule of law og folkelig legitimitet som nationalstater. Det westfalske suverænitetsspil er baseret på ikke-intervention, forstået som en ret og pligt til ikke-indblanding samt selvhjælp, idet staterne er individuelt ansvarlige for at stå for egen sikkerhed og velfærd. ${ }^{5}$
Derudover er spillet baseret på gensidighed, forstået som lige og fair konkurrence ud fra et noget-for-noget-princip (Sørensen 1999, 598-600). Mange teoretikere inden for International Politik, måske særligt neorealister, ser det westfalske suverænitetsspil som det standardspil, der spilles af alle uafhængige stater, men dermed overser de en række væsentlige relationer, der også eksisterer mellem stater i dag (Sørensen 1999, 600).

Det postkoloniale spil er, som navnet antyder, opstået, efter at afkoloniseringen skabte en række nye stater. Idealtypisk er spillerne svage stater med substantielle mangler i forhold til statslighed. Ofte er besiddelsen af de basale kriterier om territorium, folk og regering mere formelle end reelle: Der er ikke kontrol med territoriet; befolkningen er splittet, og der er ingen sammenhængende, national økonomi. Ideen om nationen har kun fremstået negativt i forhold til at slippe af med kolonimagten, og da dette projekt først var lykkedes, var der ikke nogen positiv definition af fællesskabet tilbage (Sørensen 1999, 600-602). Det internationale samspil er ikke baseret på selvhjælp, idet de svage postkoloniale stater er afhængige af hjælp fra de udviklede lande. Normen om ikke-intervention sættes under pres ved, at bistandsdonorer får en del indflydelse i disse lande, og i yderste konsekvens ved det internationale samfunds intervention i en failed state. Relationerne i det postkoloniale suverænitetsspil bygger på ikke-reciprocitet, da de postkoloniale stater er afhængige af fordelagtige aftaler (Sørensen 1999, 601).

Det postmoderne spil adskiller sig fra det (moderne) westfalske suverænitetsspil ved at foregå mellem stater $i$ en transnationalt integreret og globaliserede økonomi, hvor det politiske fællesskab ikke længere er eksklusivt bundet til nationalstaten. Den økonomiske globalisering skaber incitamentet for et supranationalt samarbejde da et sådant samarbejde er en måde at genvinde noget af den politiske reguleringsmagt, som er tabt på nationalt niveau grundet globaliseringen (Sørensen 1999, 602). Spillet er derfor baseret på intenst samarbejde mellem stater f.eks. i EU. ${ }^{6}$ Normen om ikke-intervention modificeres, idet „[s] tates bargain with their sovereignty, their territorial authority, in the sense that they allow other states to influence the regulation of their domestic affairs in return for influence over the domestic affair of these other countries." (Sørensen 1999, 602). Ligeledes modificeres reciprocitet, da det postmoderne spil baserer sig på samarbejde frem for konkurrence og involverer en grad af omfordeling over nationale grænser. F.eks. får fattigere regioner i EU særlig fordelagtig behandling. Dette kan ligne bistandsregimet i det postkoloniale spil, men der er en afgørende forskel: Inden for EU er der institutionaliseret mulighed for at kontrollere, hvordan pengene bruges (Sørensen 1999, 603). 
Tabel 1: Idealtypiske suverænitetsspil (egen fremstilling fra Sørensen 1999, 598-604)

\begin{tabular}{|c|c|c|c|}
\hline & Stat, idealtype & Ikke-intervention & Reciprocitet \\
\hline Westfalsk & $\begin{array}{l}\text { Selvbærende national økonomi. } \\
\text { Rule of law og folkelig legitimitet. } \\
\text { Nationalstat. }\end{array}$ & $\begin{array}{l}\text { Ikke-intervention som ret og pligt til ikke-indblanding, } \\
\text { selvhjælp. } \\
\text { Reciprocitet indebærer lige og fair konkurrence, } \\
\text { 'noget-for-noget-princip'. }\end{array}$ & $\begin{array}{l}\text { Reciprocitet indebærer lige og fair kon- } \\
\text { kurrence, 'noget-for-noget- princip'. }\end{array}$ \\
\hline Postkolonialt & $\begin{array}{l}\text { Ingen sammenhængende national økonomi. } \\
\text { Ringe eller ingen kontrol over territorium. }\end{array}$ & $\begin{array}{l}\text { Ingen sammenhængende national økonomi. } \\
\text { Ringe eller ingen kontrol over territorium. }\end{array}$ & $\begin{array}{l}\text { Ikke-reciprocitet, i stedet præferentielle } \\
\text { aftaler. }\end{array}$ \\
\hline Postmoderne & $\begin{array}{l}\text { Transnationalt integrerede, globaliserede } \\
\emptyset \text { øonomier. }\end{array}$ & $\begin{array}{l}\text { Politisk fællesskab ikke udelukkende bundet til national- } \\
\text { staten. Legitim intervention i medlemsstaters nationale } \\
\text { anliggender. }\end{array}$ & $\begin{array}{l}\text { Grad af omfordeling over nationale } \\
\text { grænser og til regioner; præferentiel } \\
\text { behandling, men med samarbejde og } \\
\text { kontrol. }\end{array}$ \\
\hline
\end{tabular}

\section{Fra idealtyper til argumentatoriske strategier}

Problemet med Sørensens idealtypiske spil er, at de ikke tager højde for, hvad der sker, når disse forskellige idealtyper mødes. Hvad sker der f.eks. når en stat, der normalt spiller postmoderne spil, skal forholde sig til en aktør, der normalt spiller postkoloniale spil? Suverænitetsspil er ikke nødvendigvis knyttet til en bestemt geografisk region eller en bestemt stat eller aktør. Den samme aktør kan spille forskellige spil. Vi har altså brug for at forstå suverænitetsspil som relationelle og mere volatile. Vi ser dem i stedet som udtryk for forsøg på at præsentere subjektivitet på en bestemt måde. For at forstå hvordan det sker, må vi have et teoretisk fokus på det diskurs-strategiske element i suverænitetsspil. Vi kobler derfor forestillingen om idealtyper og de forskellige goder og byrder, der følger med et bestemt spil, med den argumentationsmodel, der blev udviklet af retorikeren Stephen Toulmin i 1950'erne. ${ }^{7}$

Konkret identificeres de argumentatoriske strategier gennem en afdækning af, hvordan aktører (i dette tilfælde OLTerne) argumenterer ved hjælp af en „påstand“, som sandsynliggøres af et „belæg“ og en ofte implicit „hjemmel“ - det bagvedliggende princip, som er forudsætningen for, at argumentet (påstand + belæg) kan vinde modtagerens tilslutning (Toulmin 1958). Vi fokuserer på, hvordan OLTerne underbygger deres krav og ønsker (påstand) i høringssvarene med konkrete belæg, samt hvilke bagvedliggende antagelser om suverænitets-relationer (i dette tilfælde EU-OLT-relationen), der ligger til grund for, at denne argumentation kan betragtes som meningsfuld og legitim (hjemmel). Hjemlen er særligt interessant, fordi den danner grundlaget for, at en argumentation kan virke overbevisende på modtageren - $\mathrm{i}$ dette tilfælde Kommissionen og de forskellige medlemslande: Hjemlen i hvert argument er knyttet til et bestemt suverænitetsspil.

$\mathrm{Vi}$ identificerer argumenterne for en bestemt suverænitetsrelation ved at se på OLTernes svar på Kommissionens oplæg til reform. Høringsprocessen på baggrund af Kommissionens grønbog er OLTernes væsentligste mulighed for at påvirke deres nye position. Kommissionen har udmeldt, at der i grønbogsprocessen ikke er nogle svar, der er givet på forhånd - og grønbogen former sig (som det fremgår af artiklens næste afsnit) på mange måder som en opfordring til OLTerne om at beskrive, hvordan de ser sig selv og deres fremtidige relation til EU. Derfor er OLTernes svar på grønbogen et oplagt analysemateriale, når vi interesserer os for deres subjektivitet. Svarene på grønbogen læses med et fokus på, hvordan OLTerne positionerer sig som aktører, og hvordan de italesætter sig selv og „virkeligheden“. Disse italesættelser udtrykker OLTernes strategier for at overbevise modparterne om rimeligheden i en bestemt fordeling af goder og forpligtelser, og dermed de suverænitetsspil, de forsøger at italesætte sig inden for.

\section{Analyse: OLTernes svar på EUs invitation}

Grønbogen kan ses som EUs forsøg på at indhente argumenter til at legitimere et skift fra en postkolonial til en postmoderne relation. Den postkoloniale relation indebærer et asymmetrisk afhængighedsforhold mellem OLTer og EU, der tildeler OLTerne goder uden forpligtelser. Eksempelvis har OLTernes varer toldfri adgang til EUs indre marked, ligesom OLT-borgere har rettigheder som EUborgere, når de flytter til EU - mens OLTerne kan indføre told på varer fra EU og lægge begrænsninger på EUborgeres bosætning, erhverv, ret til at købe ejendom osv. I modsætning til den postkoloniale relation indebærer den postmoderne relation et gensidigt forhold med både goder og forpligtelser for OLTerne. Den postkoloniale relation kan primært retfærdiggøres i EUs historiske ansvar, mens den postmoderne baserer sig på, at samarbejdet skal have værdi for begge parter.

Den nuværende EU-OLT-relation er i ifølge Kommissionen et udviklingssamarbejde uden gensidighed, fordi det ikke pålægger OLTerne nogen „forpligtigelser“. Den nuværende (postkoloniale) relation er derfor ikke i „,begge parters interesse" (Kommissionen 2008, 10). Den drager 
ikke fordel af „det potentiale, som de oversøiske lande og territorier har som strategiske forposter for udbredelsen af EUs værdier på verdensplan“ (Kommissionen 2008, 2).

Kommissionen ønsker i stedet en ny relation, der kan karakteriseres som postmoderne, idet den skal baseres på en fælles europæisk identitet og et gensidigt ansvar. OLTerne fremstilles i grønbogen som mere end blot tredjelande, idet „de og EU er medlem af samme familie“ (Kommissionen 2008, 2). OLTerne deler værdier og historie med Europa og udgør EUs „yderste grænseland“ (Kommissionen 2008, 6). ${ }^{8}$ Når OLTerne betragtes som en del af fællesskabet, giver det dem også ansvar og forpligtelser heroverfor. I grønbogen stilles således spørgsmålet om, hvilken strategisk betydning OLTerne har, og hvilke konkrete pligter, det bør indebære for dem (Kommissionen 2008, 10). EU efterspørger grundlæggende en mere postmoderne relation (Kommissionen 2008, 13):

Hvordan kan partnerskabet mellem de oversøiske lande og territorier og EU gøres mere aktivt og mere gensidigt, i begge parters interesse? Hvilke konkrete pligter kan dette indebære for de oversøiske lande og territorier og den medlemsstat, de er knyttet til (inden for deres forfatningsmæssige rammer)?

Grønbogsprocessen har til formål at få fastlagt den raison d'être, der fortsat skal retfærdiggøre en særlig og favorabel relation for OLTerne i forhold til EU. Dette søges i grønbogen lanceret ved at give EU-OLT-relationen en mere postmoderne retning med fælles identitet og gensidigt ansvar. Høringsprocessen og dermed også OLTernes svar har altså til formål at indholdsudfylde denne fremstilling af relationen eller alternativt angive en anden, mere legitim retning for forholdet. I det følgende analyseres, hvordan OLTerne responderer på denne efterspørgsel i deres høringssvar, og dermed hvordan de udnytter det mulighedsvindue, som grønbogsprocessen udgør, til at fremme egne interesser.

\section{Det postkoloniale subjekt med 'ret' til bistand fra EU}

Det er et gennemgående træk, at OLTerne argumenterer for, at de har en ret til at modtage hjælp fra EU. Dette kan læses som en postkolonial italesættelse. I nogle høringssvar fremlægger de ligefrem en ønskeseddel, hvor de redegør for egne behov uden at argumentere for eller overbevise modtageren om, hvorfor dette pålægger EU et ansvar:
Anguilla is at a disadvantage with regards to the present criteria for allocation of funds, Anguilla will lose out with the use of population and the population weighted indicator of GDP. (Anguilla 2008, 1, kursivering tilføjet)

Denne argumentation fremstiller OLTen som svag. Konsekvensen er, at det overlades til EU og moderlande at omsætte OLTernes behov i den videre politiske genforhandling, som grønbogsprocessen er et oplæg til.

Flere OLTers høringssvar indeholder dog forskellige argumenter for, hvorfor OLTerne har ret til bistand fra EU. Disse argumenter handler om OLTernes udviklingsbehov (St. Helena 2008, 8) og sårbarhed som udsatte mikroøkonomier, der for manges vedkommende ikke vil være i stand til at opretholde deres moderne samfund med europæisk levestandard uden hjælp fra EU. Denne situation har EU-landene selv været med til at skabe, og de har derfor et historisk ansvar for at vise OLTerne solidaritet. ${ }^{\text {? }}$ Samme belæg anvendes til at argumentere for, hvorfor OLTernes handelsadgang til EU bør være mere favorabel end AVS-landenes (De Nederlandske Antiller 2008, 7). I Traktaten har medlemslandene forpligtet sig på et formål for EU-OLT-relationen, nemlig ,at fremme den økonomiske og sociale udvikling "10 i OLTerne, hvilket pålægger $\mathrm{EU}$ at opretholde sit engagement uden at kunne forlange, at OLTerne f.eks. påtager sig et ansvar til gengæld. Det ville derfor være både inkonsistent og traktatstridigt at løbe fra EUs forpligtelse til at indgå i denne ulige relation.

Flere OLTer argumenterer for EUs forpligtelse til at støtte OLTerne med henvisning til EU-medlemslandenes uretmæssige handlinger i forhold til henholdsvis kolonisering og klimaforandringer. Fransk Polynesien henviser f.eks. implicit til kolonitiden ved at fremhæve, at det $ø$ nsker at mindske sin økonomiske afhængighed af den tidligere kolonimagt Frankrig, alt imens det understreges, at denne ambitiøse politik kræver støtte fra Frankrig såvel som EU (Fransk Polynesien 2008, 3). Her sker en aktivering af den westfalske norm om selvstændighed og uafhængighed. Men det sker inden for en italesættelse af relationen som postkolonial, hvor det er moderlandet og EUs opgave at støtte og facilitere denne øgede uafhængighed. Det Fransk Polynesiske Conseil Economique, Social et Environnemental refererer mere eksplicit til den koloniale fortid ved at påpege, at moderlandet og EU står i historisk gæld til Fransk Polynesien, fordi sidstnævnte har lagt territorium til atomprøvesprængninger (Fransk Polynesisk CESE 2008, 1). Fransk Polynesien har på denne måde (ufrivilligt) bidraget til fransk og europæisk sikkerhed, hvilket bør skabe et bånd og en solidaritet mellem parterne, som forpligter EU til at bidrage til Fransk Polynesiens udvikling. Det historisk baserede 
argument med bebrejdelser for kolonifortiden udbygges i De Britiske Jomfruøers høringssvar med et krav om, at EU påtager sig et aktuelt ansvar for klimaforandringernes negative konsekvenser (f.eks. orkaner og oversvømmelser), som OLTerne er særligt udsatte overfor (De Britiske Jomfruøer 2008, 13). Selvom der måtte være nogle medlemslande, der mener, at EU ikke skal blive ved at betale af på nogle få moderlandes koloniale 'gæld', argumenterer De Britiske Jomfruøer altså for, at alle EU-medlemslande har en forpligtelse til at vedblive at hjælpe OLTerne pga. de nye problemer, som klimaforandringerne forårsager, og som EU-landene bærer et stort medansvar for:

This is the result not of their own actions but of the activities of polluting countries, which include numerous medium-sized and large EU Member States ... There is a strong moral case for EU countries as a whole to maintain the tradition of solidarity by helping OCTs [OLTer] become more resilient to the potential damage of climate change to their long-term sustainability. (De Britiske Jomfruøer 2008, 13, kursivering tilføjet)

Medlemslandenes medvirken til den globale opvarmning påfører i dette argument EU et moralsk ansvar for OLTernes økologiske sårbarhed.

På den måde argumenterer disse OLTer for en fortsættelse af den nuværende postkoloniale udviklingsrelation mellem EU og OLT. Rationalet er grundlæggende parallelt med EUs relation til AVS-landene: AVS-landene og OLTerne har brug for hjælp, og EU har en historisk og/eller moralsk forpligtelse til at give denne hjælp til sine forhenværende kolonier. Men parallellen til AVS-landene går kun på retten til støtte. Flere OLTer fremhæver, at OLTerne bør underlægges mindre bureaukratiske krav end AVS-landene, dels fordi de qua deres størrelse er mere sårbare, men primært fordi OLTerne er tættere knyttet til Europa og har ret til en endnu tettere relation end AVS-landene:

[T] he Community's relationship with ACP countries [AVS-landene] has been improved to such a degree that in some cases they are better than those between OCTs and the Community. As a recognised part of the European family and not independent countries, OCTs should be able to enjoy a preferential relationship with the Community. (Falklandsøerne 2008, 4, kursivering tilføjet)

Fælles for disse argumenter er, at de fremhæver EUs forpligtelser over for OLTerne, mens de ignorerer mulige OLT-forpligtelser over for EU. Dermed italesætter OLT- erne relationen som postkolonial på trods af Kommissionens efterspørgsel efter postmoderne argumenter, der også stiller krav til OLTerne. Belæggene om EUs historiske eller aktuelle ansvar over for OLTerne baserer sig på den bagvedliggende hjemmel om at relationen mellem EU og OLTerne er asymmetrisk, og at EU har et grundlæggende ansvar for at hjælpe de sårbare OLTer.

\section{Postkoloniale subjekter i postmoderne klæder}

Mange af OLTernes høringssvar forsøger dog også at imødekomme Kommissionens efterlysning af et mere ligeværdigt partnerskab. I grønbogen antydes to måder, hvorpå OLTerne kan have en særlig værdi for EU som henholdsvis strategiske „forposter" eller regionale „erfarings- og ekspertisecentre" (Kommissionen 2008, 11). OLTerne forsøger at indholdsudfylde disse postmoderne visioner, og efterspørger større medbestemmelse for partnerskabet, men formulerer ikke nogle forpligtelser for dem selv.

Flere OLTer fremhæver i deres høringssvar, at de deler europæiske værdier om demokrati, menneskerettigheder, retsstaten, good governance og bæredygtig miljøpolitik, hvormed de italesætter en fælles identitet med en postmoderne relation til EU:

These values which the EC seeks to promote to third countries are already part of our society ... [We] are direct links into otherwise remote areas of the globe enabling the EU to influence policies, values and standards. (Falklandsøerne 2008, 1; 5)

Som bærere af de europæiske værdier ... er OLTerne fuldt ud i stand til at bidrage til EUs indflydelse. (Fransk Polynesien 2008, 8, egen oversættelse)

OLTerne mener altså at kunne medvirke til at udbrede de europæiske værdier og dermed EUs indflydelse i andre regioner af verden (Fransk Polynesien 2008, 9). Mayotte hævder ligefrem, at denne rolle som forpost er så værdifuld for EU, at den retfærdigg ør frigivelsen af nye økonomiske midler til at finansiere det $(2008,5)$. Ingen af OLTerne konkretiserer dog, hvordan de vil bidrage til udbredelsen af EUs værdier, taget i betragtning af, hvor relativt isoleret mange af øerne er placeret geografisk. OLTerne forsøger at argumentere for, at der her er tale om en winwin-situation, hvor de har noget at tilbyde EU. Men med få undtagelser ${ }^{11}$ underbygger de ikke denne postmoderne italesættelse ved at vise et engagement og påtage sig et ansvar. I stedet for at uddybe, hvordan OLTerne kunne påtage sig forpligtelser, understreger de blot vigtigheden 
af, at det sker frivilligt, og at Kommissionen tager initiativ til at understøtte det. Dermed besvarer de ikke Kommissionens spørgsmål om, hvilke „konkrete pligter“ dette kunne indebære for OLTerne (Kommissionen 2008, 13). De fleste OLTer omtaler dog den potentielle rolle som værdimæssige forposter helt uden at berøre muligheden for, at dette kunne indebære en gensidighed i ansvar eller forpligtelser fra OLTernes side. Flere OLTer mener desuden, at de kan være „erfaringscentre“ i forhold til deres nabolande og derigennem udbrede europæiske standarder (eks. Fransk Polynesien 2008, 5; Mayotte 2008, 2). Dette foreslås dog også uden nogen bud på, hvordan OLTerne selv kan bidrage til at realisere denne vision om at udgøre videnscentre i deres respektive regioner. Falklandsøerne vælger endda helt åbent at formulere deres eventuelle potentiale som et spørgsmål til Kommissionen $(2008,2)$.

Mange af OLTerne efterspørger mere information og en anerkendelse som spillere, der skal høres og inddrages i Bruxelles. Grønland mener f.eks., at man bør lægge en fælles strategi for, hvordan politisk ejerskab og empowerment kan sikres for hver OLT (Grønland 2008, 7). OLTernes indholdsudfyldelse af et mere gensidigt partnerskab er dermed baseret på større inddragelse men ikke større forpligtigelser for dem.

Nogle af OLTerne forsøger altså at argumentere indenfor den postmoderne italesættelse af den relation, som Kommissionen lancerer i grønbogen. Denne argumentation baserer sig på en påstand om, at OLTerne kan betragtes som ligeværdige partnere, der ikke blot er en byrde for EU men også har noget at tilbyde. Dette underbygges med en række belæg, hvor OLTerne gentager Kommissionens udspil om forposter og erfaringscentre. Men OLTerne indholdsudfylder ikke disse relativt luftige visioner med et konkret ansvar eller forpligtelser, sådan som Kommissionen efterspørger. Tværtimod fastholder de, at det er Kommissionens opgave at undersøge potentialet nærmere og herefter facilitere en virkeliggørelse af det. Argumentationen fremstår derfor inkonsistent, fordi OLTerne på den ene side siger, at de har noget at tilbyde EU og på den anden side faktisk undlader at tilbyde noget og i stedet beder Kommissionen tage ansvaret som i den postkoloniale relation. Dette underminerer den postmoderne italesættelse om, at OLTerne har en værdi for EU og er villig til at indgå $\mathrm{i}$ en relation med gensidigt ansvar og forpligtelser. Der er derfor tale om en inkonsistent postmoderne italesættelse - reelt med postkolonialt indhold.

\section{Grønland - et westfalsk subjekt in spe?}

Grønland er den eneste OLT, der nok ser sig selv som periferien af det europæiske fællesskab, men som stærk nok til at kunne indgå i et westfalsk noget-for-noget-spil med centret: Grønland præsenterer sig selv som delvist ligeværdig: „A future model [of the OCT-EC association] should take into account the European strategies vis-àvis Greenland as an OCT as well as a strategic partner." (Grønland 2008, 11, kursivering tilføjet) - en strategisk partner, som kan gøre krav på, at EU indgår i en bilateral dialog (Grønland 2008, 7). Baggrunden er, at Grønland beskriver sig selv som i besiddelse af noget, EU gerne vil have - og man placerer sig implicit i en position, hvor man har alternative handlemuligheder end blot at tilbyde det til EU. Hermed beskriver Grønland sig selv som en spiller, der kan forhandle selvstændigt med EU.

Dette sker for det første ved at italesætte et spil, hvor Grønland ønsker at opnå en loyalitetsbelønning for at samarbejde med EU frem for andre parter som f.eks. USA. I denne type strategi søger Grønland at opnå goder som belønning for ikke at bevæge sig væk fra centret og hen imod et andet (Parker 2008, 13). Dette fremgår af Grønlands høringssvar, hvor noget af det første, Grønland bruger tid på i sin besvarelse, er at understrege landets geostrategiske vigtighed for $\mathrm{EU}$ :

\section{Geo-politics}

The strategic importance of Greenland to the EU as a whole lies first and foremost in Greenland's geographical position as a stepping stone between Europe and North America. In that sense, Greenland poses a geopolitical opportunity for the EU. (Grønland 2008, 3, fremhæevet i org.)

For det andet påpeger Grønland sine unikke ressourcer, som er attraktive for EU: Grønland er „the laboratory in relation to the monitoring of the changing climate" (Grønland 2008, 2, understreget i org.) og Grønland er "partly the place to identify new possibilities that arise with the melting of the ice in terms of potential and future shipping routes and maritime traffic" (Grønland 2008, 2, understreget i org.). Tilsvarende italesætter Grønland sig som rådende over ,an unprecedented energy potential“, hvilket giver Grønland en uomgængelig subjektivitet: „In terms of energy security Greenland can be a future important player and can be a facilitator in this respect.“ (Grønland 2008, 2).

Grønland hævder dermed sig selv som en vigtig spiller, som EU har en interesse $i$ at bibeholde gode relationer til. Grønland mener, at man har tilstrækkelig strategisk vægt til at bruge denne som en bargaining chip og forfølge en strategi, hvor man truer med at tilbyde sine strategiske ressourcer til andre samarbejdspartnere.

Dette fremgår af, at man i høringssvaret fremhæver sin harme over EUs forbud mod handel med sælprodukter - og direkte kæder problemstillingen sammen med, at 
EU i fremtiden bør overveje, hvordan man handler over for Grønland, hvis man vil bevare et godt forhold og dermed adgang til Grønlands strategiske ressourcer:

\section{This is for Greenland an issue of principles and} will be the cause of strong reactions which will not be beneficial to the strong and constructive relationship between the EU and Greenland. (Grønland 2008, 3)

Grønland prøver her at få sine krav igennem ved at presse EU og indirekte true med at fratage EU dets adgang til Grønlands ressourcer, såsom indflydelse i Arktis, der vinder ny strategisk betydning i takt med, at isen smelter. Argumentet for, at Grønland kan italesætte relationen som westfalsk er, at man besidder nogle ressourcer, som EU ikke har råd til at miste adgangen til.

\section{Konklusion: Argumenter om Arktis som ressource}

Arktis spiller en væsentlig rolle for Grønlands forhold til EU. Grønland bruger Arktis til at italesætte sin subjektivitet og sit forhold til EU som ligeværdigt. Modsat de øvrige oversøiske lande og territorier præsenterer Grønland sig som mere westfalsk end postkolonial. For at forstå hvordan det sker, har vi videreudviklet Georg Sørensens begreb om tre typer suverænitetsspil: det westfalske, det postkoloniale og det postmoderne. Traditionel teori om international politik har nemlig, pga. sin statscentrisme, svært ved at forstå små ikke-statslige aktører og deres handlemuligheder. Sørensens teoretiske apparat mangler en forståelse af relationerne mellem forskellige suverænitetsspil og deres ikke-materielle karakter. For at løse dette problem videreudviklede vi ideen om suverænitetsspil i en diskursiv retning. Vi koblede tanken om idealtypiske spil til Toulmins retoriske argumentationsstrategi.

Artiklen undersøgte konkret, hvordan EUs oversøiske lande og territorier (OLTerne) argumenterer for en særlig subjektivitet i forhold til EU gennem en analyse af deres italesættelse af relationen. Vi betegner disse italesættelser af EU-OLT-relationen som strategier, fordi de er udtryk for, hvilke argumenter OLTerne anvender i optakten til genforhandlingen af OLT-ordningen. Tabellen nedenfor opsummerer analysens resultater.

Alle OLTernes høringssvar har samme målsætning: OLTerne skal vedblive at modtage støtte fra EU. Nogle taler for, at OLTernes goder og rettigheder skal udvides, mens andre blot fastholder, at den relativt favorable position ikke må forringes under genforhandlingen på trods af OLTernes høje BNP.

Der er tale om to parallelle strategier, som begge har til formål at sikre OLTernes fortsatte favorable position med støtte fra EU. På den ene side fastholdes en postkolonial italesættelse, som henviser til, at EU har et ansvar for at kompensere for OLTernes sårbarhed. På den anden side lanceres en relativt passiv 'Vi-venter-på-Kommissionen'strategi, hvor OLTerne bakker op om Kommissionens postmoderne italesættelse, men lader det - på postkolonial vis - være op til EU og evt. moderlande at konkretisere argumenterne på en meningsfuld og overbevisende måde i den videre genforhandling.

Når man ser nærmere på OLTernes forsøg på en postmoderne italesættelse af relationen, fremstår det inkonsistent. Der er tale om pseudo-argumentation, hvor OLTerne gentager Kommissionens postmoderne argumenter, men ikke indholdsudfylder dem ved at påtage sig et ansvar eller konkretisere nogle forpligtigelser, som de er villige til at påtage sig. Interessant nok protesterer ingen

Tabel 2: Sammenfatning af OLTernes strategier og argumentation

\begin{tabular}{|c|c|c|c|}
\hline \multirow[t]{2}{*}{ Strategi } & \multicolumn{3}{|c|}{ Argumentation } \\
\hline & Påstand & Belæg & Hjemmel \\
\hline $\begin{array}{l}\text { Fastholde goder og rettigheder samt } \\
\text { undgå forpligtelser. Retfærdiggjort } \\
\text { vha. postkolonial italesættelse af } \\
\text { relationen. }\end{array}$ & $\begin{array}{l}\text { OLTerne har ret til bistand uden } \\
\text { forpligtelser eller indblanding. }\end{array}$ & $\begin{array}{l}\text { OLTerne har behov for hjælp, som EU bærer et } \\
\text { historisk og aktuelt ansvar for at give. }\end{array}$ & $\begin{array}{l}\text { Postkolonial italesættelse af } \\
\text { EU-OLT-relationen som asymmetrisk, } \\
\text { der medfører et EU-ansvar for OLT- } \\
\text { ernes sårbarhed og afhængighed. }\end{array}$ \\
\hline $\begin{array}{l}\text { Udvide goder og rettigheder samt } \\
\text { undgå forpligtelser ved passivt at } \\
\text { afvente Kommissionens videre udspil. } \\
\text { Retfærdiggjort vha. Kommissionens } \\
\text { postmoderne italesættelse af rela- } \\
\text { tionen. }\end{array}$ & $\begin{array}{l}\text { EU skal betragte OLTerne som } \\
\text { ligeværdige partnere, der har } \\
\text { noget at tilbyde. }\end{array}$ & $\begin{array}{l}\text { OLTerne kan udgøre forposter for EU og ud- } \\
\text { brede ekspertise og EU-standarder regionalt og } \\
\text { allerede indgår i et gensidigt, institutionaliseret } \\
\text { partnerskab med EU, som blot skal styrkes } \\
\text { med øget inddragelse. }\end{array}$ & $\begin{array}{l}\text { Postmoderne italesættelse af } \\
\text { EU-OLT-relationen som et gensidigt } \\
\text { win-win og havende værdi for begge } \\
\text { parter, fordi EU har regionale interes- } \\
\text { ser i OLTernes nærområder. }\end{array}$ \\
\hline $\begin{array}{l}\text { Grønland: Fastholde goder ved at 'true' } \\
\text { EU. Retfærdiggjort vha. westfalsk } \\
\text { italesættelse af relationen. }\end{array}$ & $\begin{array}{l}\text { Grønland skal have loyalitets- } \\
\text { belønning for ikke at vælge an- } \\
\text { dre alliance-partnere end EU. }\end{array}$ & $\begin{array}{l}\text { Grønland har geostrategisk værdi for EU i Arktis } \\
\text { og som forbindelsesled til Nordamerika, hvilket } \\
\text { bringes i fare af EUs manglende respekt. }\end{array}$ & $\begin{array}{l}\text { Westfalsk italesættelse af } \\
\text { EU-OLT-relationen som et noget-for- } \\
\text { noget nulsumsspil. }\end{array}$ \\
\hline
\end{tabular}


OLTer over den postmoderne italesættelse, og de afviser heller ikke, at de er i stand til påtage sig de forpligtelser, som en postmoderne relation medfører. Sandsynligvis fordi de opfatter den postmoderne italesættelse som en mulighed for et nyt raison d'être for EU-OLT-relationen, som kan opretholde den favorable position.

Mindre inkonsistent er Grønlands forsøg på en westfalsk italesættelse af relationen. Vel ledsages den westfalske italesættelse af postkoloniale italesættelser af relationen andre steder i samme dokument - men det er den westfalske italesættelse, som indleder Grønlands svar på Grønbogen og som dermed sætter betingelserne for, hvordan de efterfølgende postkoloniale argumenter kan læses: Grønland stiller krav til EU om at opretholde bistanden til Grønland, for at EU kan opretholde adgangen til de geostrategiske ressourcer, som Grønland tilbyder. Grønland beskriver altså, hvordan man har noget at handle med i relationen til EU.

Denne italesættelse er mindre inkonsistent - men den er måske også mere risikabel. Hvad nu, hvis EU ikke accepterer den beskrivelse, Grønland leverer af sig selv som en strategisk interesse for EU? Derfor er det helt afgørende, at væsentlige dele af de ressourcer, EU ifølge Grønland kan gå glip af, forskydes til fremtiden: Når isen smelter og de arktiske muligheder (mineraler, olie, transportveje) forøges. Dermed er Grønland godt nok stadig afhængig af EUs accept af sin værdi i westfalske byttehandler - men man skriver sig ind i en diskurs om Arktis som den nye frontier, der åbner sig og tilbyder sin bonanza af nye, tilgængelige ressourcer. I denne diskurs - som finder stigende udbredelse på den nordlige halvkugle (cf. Emmerson 2010) - tildeler klimaforandringerne Grønland en rolle med langt større subjektivitet, end den offerrolle som de fleste OLTer giver sig selv, når de taler om deres sårbarhed over for klimaforandringer.

\section{Referencer}

Adler-Nissen, R \& UP Gad 2010, 'Postcolonial Sovereignty Games in the Margins of Europe', draft introductory chapter to an edited volume on The Overseas Countries and Territories of The European Union to be presented at the conference 'Micro-Polities in the Margins of Europe', Nuuk, Greenland,18-19 April, 2011.

Adler-Nissen, R \& T Gammeltoft-Hansen 2008 (red.), Sovereignty Games: Instrumentalizing State Sovereignty in Europe and Beyond, Palgrave Macmillan, New York.

Anguilla 2008, 'Aguilla's Response to Green Paper Questionnaire', Høringssvar til KOM(2008) 383 (Alle høringssvar til $\mathrm{KOM(2008)} 383$ lokaliseret 08.03.2010 på http://ec.europa.eu/development/icenter/ repository/Contribution-Consultation-3841-Green-paper-on-thefuture-relations-between-EU-and-overseas-countries-territories-V2. zip).
Baldacchino, G \& D Milne 2006, 'Exploring sub-national island jurisdictions: an editorial introduction', The Round Table, vol. 95, issue 386, pp. 487-502.

Bertram, G 2006, 'Introduction: The MIRAB model in the twentyfirst century', Asia Pacific Viewpoint, vol. 47, no. 1, pp. 1-13.

Browning, CS \& P Joenniemi 2004, 'Contending Discourses of Marginality: The Case of Kaliningrad', Geopolitics, vol. 9, no. 3, pp. 699-730.

Browning, CS \& P Joenniemi 2008, 'Gibraltar, Jerusalem, Kaliningrad: Peripherality, Marginality, Hybridity', in N Parker (red.), The Geopolitics of Europe's Identity - Centers, Boundaries, and Margins, Palgrave MacMillan, New York.

Caymanøerne 2008, 'Cayman Islands response to the Green Paper on Future Relations between the EU and the OCTs, Leader of Government Businesss, Hon. D. Kurt Tibbetts, JP', Høringssvar til KOM(2008) 383.

De Britiske Jomfruøer 2008, 'European Commission Green Paper on Future Relations between the EU and the Overseas Countries and Territories, COM (2008) 383 final. Response by the Government of the British Virgin Islands, 30.10.2008', Høringssvar til KOM(2008) 383.

De Nederlandske Antiller 2008, 'Standpunkt Regering van de Nederlandse Antillen. Groenboek Europese Commissie over de toekomstige betrekkingen tussen de EU en de Landen en Gebieden Overzee (LGO)', Horingssvar til KOM(2008) 383.

Emmerson, C 2010, The Future History of the Arctic, PublicAffairs Books, New York.

Falklandsøerne 2008, 'Political Considerations for the Falkland Islands in Respect of the EU Green Paper on the Overseas Territories, The Falkland Islands Government, 16.10.2008', Horingssvar til KOM(2008) 383.

Fransk Polynesien 2008, 'Réflexions sur un partenariat rénové des Pays et Territoires d'Outre-Mer (PTOM) avec l'Union européenne (UE). La réponse du gouvernement de la Polynésie française. Le Président, 15.10.2008', Høringssvar til KOM(2008) 383.

Fransk Polynesisk CESE 2008, 'L'avis du Conseil Economique, Social et Environnemental (CESE) de la Polynésie française à pour objet l'examen d'une consultation publique sur la renovation de la relation d'association entre les Pays et Territoires d'Outre-Mer (PTOM) et l'Union européenne (UE)', Horingssvar til KOM(2008) 383.

Grønland 2008, 'Greenlandic response to the Green Paper on the future relations between EU and the OCTs Minister for Finances and Foreign Affairs, 17.10.2008', Høringssvar til KOM(2008) 383.

Hannibal, I \& K Holst 2010, Europa's Permanente Paradoks? - EUs oversøiske lande og territoriers suverænitetsspil i Bruxelles, speciale, Institut for Statskundskab, Københavns Universitet.

Joenniemi, P \& N Parker 2008, 'Power and Marginality in the International System' in N Parker (red.), The Geopolitics of Europe's Identity - Centers, Boundaries, and Margins, Palgrave MacMillan, New York.

Kommissionen for de Europæiske Fællesskaber 2008, Gronbog. De fremtidige relationer mellem EU og de oversøiske lande og territorier, $\operatorname{KOM}(2008)$ 383, 25.6.2008. Kommissionen, Bruxelles.

Laïdi, Z 2008, La norme sans la force. L'énigme de la puissance européenne, Presses de Sciences Po, Paris.

Lissabontraktaten 2008, Lissabontraktaten sammenskrevet med det galdende traktatgrundlag, Folketingets EU-Oplysning, Christiansborg.

Mayotte 2008, 'Délibération de la séance plénière du 29 Septembre 2008 relative à une contribution du conseil général au Livre vert portant à l'avenir des relations entre l'Union européenne et les pays et territoires d'outre-mer (PTOM)', Høringssvar til KOM(2008) 383. 
McElroy, JL \& KB Pearce 2006, 'The advantages of political affiliation: Dependent and independent small-island profiles', The Round Table, vol. 95, issue 386, pp. 529- 539.

Ny Kaledonien 2008, 'Contribution de la Nouvelle-Calédonie à la consultation publique lancée par la Commission européenne sur le livre vert concernant l'avenir des relations entre l'Union européenne et les pays et territoires d'outre-mer, Le Président du Gouvernement de la Nouvelle-Calédonie, Harold Martin', Høringssvar til $\operatorname{KOM}(2008) 383$.

Parker, N 2008, 'A Theoretical Introduction: Spaces, Centers, and Margins', in N Parker (red.): The Geopolitics of Europe's Identity Centers, Boundaries, and Margins, Palgrave MacMillan New York.

Philpott, D 2001, Revolutions in Sovereignty: How Ideas Shaped Modern International Relations, Princeton University Press, Princeton.

St. Helena 2008, 'Response to the Green Paper', Horingssvar til KOM(2008) 383.

Sudre, M 2008, 'Contribution adressée à la Commission européenne sur l'avenir des relations entre l'UE et les PTOM, Présidente de la délégation des députés européens UMP, 17.10.2008', Høringssvar til $\operatorname{KOM}(2008) 383$.

Sørensen, G 1999, 'Sovereignty: Change and Continuity in a Fundamental Institution', Political Studies, vol. 47, no. 3, pp. 590-604.

Toulmin, SE 1958, The Uses of Argument, Cambridge University Press, Cambridge.

Udenrigsministeriet 2009, 'Samlenotat til Folketingets Europaudvalg vedrørende Rådsmøde (almindelige anliggender og eksterne forbindelser) den 7.-8. december 2009. 26.11.2009'. Lokaliseret 29.01.2010 på http://www.eu-oplysningen.dk/upload/ application/ pdf/f98a4159/2984_29851.pdf.

Walker, N 2003, 'Late Sovereignty in the European Union' in N Walker (red.), Sovereignty in Transition, Hart Publishing, Portland.

Walker, N 2008, 'The Variety of Sovereignty' in R Adler-Nissen \& T Gammeltoft-Hansen (red.), Sovereignty Games: Instrumentalizing State Sovereignty in Europe and Beyond, Palgrave Macmillan, New York.

\section{Noter}

1. Traktat om den Europæiske Unions Funktionsmåde (Lissabontraktaten 2008).

2. Se dog analysen i Hannibal \& Holst (2010), som denne artikel bygger på. Der findes herudover enkelte socio-økonomiske studier, oftest med regionalt fokus, f.eks. Baldacchino \& Milne (2006), McElroy \& Pearce (2006) og Bertram (2006). Hertil har katego- rien en vis juridisk opmærksomhed - senest konferencen: On Bits of Europe Everywhere: Overseas Possessions of the EU Member States in the Legal-Political Context of European Law Groningen, Holland 14. -15. december 2009. Herudover findes OLTernes situation primært belyst i enkelte analyser fra Kommissionen.

3. Grønbøger er et redskab, som Kommissionen ofte anvender som hørings- og diskussionsgrundlag i forbindelse med langsigtede lovgivningsplaner på et politikområde.

4. Sørensen mener, at suverænitet som institution hovedsageligt undergår forandringer i substantiel/empirisk statslighed (Sørensen 1999, 604). Men når man ser på, hvordan både det postkoloniale og det postmoderne suverænitetsspil er opstået, er det snarere sket med fremkomsten af nogle normer/idéer om hhv. „kolonisering er illegitimt“ og ,interdependens garanterer fred“ end ændringer $\mathrm{i}$,statslighed“, der først er kommet senere. Med disse indvendinger placerer vi os tættere på Philpott, der hævder, at det er idéer, der har genereret de store suverænitetsrevolutioner (Philpott 2001).

5. Her adskiller de europæiske lande sig f.eks. fra den westfalske idealtype, idet de ikke er de ultimative garanter for egen sikkerhed, men er afhængige af USAs beskyttelse (jf. Laïdi 2008).

6. Udviklinger associeret med postmodernitet begyndte at blive koblet til europæisk integration i midt 1990erne, hvor f.eks. James Caporaso talte om en postmoderne europæisk orden (Joenniemi \& Parker 2008, 46).

7. Adler-Nissen \& Gammeltoft-Hansen (2008), Hannibal \& Holst (2010) samt Adler-Nissen \& Gad (2010) udvikler begreber om suverænitetsspil, som på hver sin måde mere radikalt undergraver det traditionelle suverænitetsbegrebs karakter af enten/eller. Analysen i denne artikel kan imidlertid rummes inden for Sørensens teoretiske ramme.

8. Ydermere lanceres de mere juridiske argumenter om, at OLTerne har et selvstændigt kapitel i Traktaten, samt at OLT-borgerne er unionsborgere (Kommissionen 2008, 6-7).

9. Præamblen til TEUF bekræfter „den solidaritet, der knytter Europa og de oversøiske lande sammen, og som ønsker disse lande øget velstand i overensstemmelse med grundsætningerne i De Forenede Nationers pagt" (Lissabontraktaten 2008, 55).

10. Artikel 198 TEUF.

11. De Britiske Jomfruøer fremhæver f.eks. deres forpligtelse „to meet international regulatory standards“ $(2008,2)$ og deres eget ansvar for miljø og biodiversitet $(2008,7)$, mens De Nederlandske Antiller er imødekommende over for at implementere EU-standarder, hvis det sker frivilligt (De Nederlandske Antiller 2008, 2). 